\title{
Mothers' supportive care guidelines of coping Pattern for the care of their children with autism
}

\author{
Fatma Ahmed El Sobky ${ }^{1}$, Samah AbdAlla Mohamed Amer ${ }^{2}$ and Faten Shafik \\ Mahmoud Nasar ${ }^{3}$ \\ ${ }^{1,2}$ Lecturer of Pediatric Nursing, Faculty of Nursing Benha University \\ ${ }^{3}$ Assistant Professor of Pediatric Nursing, Faculty of Nursing Benha University
}

\begin{abstract}
Autism is a complex neurobehavioral condition that incorporates impairments in social interaction, developmental language and communication skills combined with rigid, repetitive behaviors. Because of the range of symptoms, this condition is now called autism spectrum disorder. It covers a large spectrum of manifestations, skills, and levels of impairment. It ranges in seriousness from a handicap that somewhat restrains otherwise normal life to a devastating disability that may require institutional care. The aim of the study: was to assess the effect mothers' supportive care guidelines of coping patterns for the care of their children with autism. The study utilized a quasi-experimental research design. Sample: A convenient sample consisted of all mothers and their children (40) diagnosed with autistic disorder. Setting: Conducted in the outpatient clinic at Benha University Hospital, and Benha Educational Hospital. The tools of data collection: Tool I: A structured interviewing questionnaire consists of three parts, Part 1: children's personnel characteristics data, as: name, age, sex, and diagnosis, Part 2: mother's personnel characteristics data, as: age, level of education, occupation, Part 3: mother's knowledge about autism. Tool 2: coping health inventory for Parent. Tool 3: mothers 'observational checklist regarding daily activity skills as a motor, cognitive, social and communication. Tool 4: family support scale .Tool 5: adaptive behavior scale .Tool 6: family supportive care guidelines for coping with children with autism, it is a booklet guidelines for mothers with autism provide them coping with their autistic children. Results: the study results revealed that there were highly significant differences between mothers' coping, and adaptive development before and after the guideline implementation, and also there were highly significant differences between mothers' knowledge before and after the guideline. Conclusion: the supportive care guidelines had an improvement in the adaptive abilities of the children with autism and had a positive effect on coping patterns of mothers to care for their children with autism. Recommendation: further family supportive care guidelines and program to improve adaptive abilities of children with autism and provide the family with effective coping strategy.
\end{abstract}

Key Wards Mothers' supportive care, autism, coping Guideline.

\section{Introduction}

Autism spectrum disorder (ASD) refers to a group of complex neurodevelopment disorders which characterized by repetitive and characteristic patterns of behavior and difficulties with social communication and interaction. The symptoms are present from early childhood and affect daily functioning. The term "spectrum" refers to the wide range of symptoms, skills, and levels of disability in functioning that may occur in people with ASD. Some children and adults with ASD are completely ready able to perform all activities of daily living while others require substantial support to perform basic activities(National Institute of Neurological Disorders and Stroke,2016).

Prevalence of autism spectrum disorder is about 1 percent of the world population. The Centers for Disease Control and Prevention (CDC) reported that the rate of children identified with an autism spectrum disorder remains at 1 in 68 children nationally. Even though ASD can be diagnosed as early as age 2 years, most of them were not diagnosed with ASD by a community provider until after age 3 years and 11 months (CDC, 2016). Prevalence of autism in U.S. children increased by 119.4 percent from 2000 (1 in 150) to 2010 (1 in 68) (CDC, 2014).

The child who is diagnosed and determined with autism spectrum disorder not just changes the life of the child diagnosed, additionally that of family members. Stress, depression, and sadness may influence family life in different unfavorable ways. Mothers of autistic children need to meet the needs of their children, address the needs of their family, as well as to make major decisions with a long way from perfect knowledge. Coping and adapting to anxieties and stress involved in being mothers to an autistic child can fortify families, additionally requires an incredible emotionally support system (Andreson, 2010) \& ( paltrow, 2015). 
Coping mechanisms are commonly termed coping strategies or coping skills. The term coping generally refers to adaptive (constructive) coping strategies. Coping skills are methods a person uses to manage unpleasant and stressful situations (carver; et al 2010).

Coping with stressful situations is one of the greatest challenges of life, as situations require strategies where one changes the self to fit the situation. Understanding the methods for family adapting is essential, as these are fundamental to subjective models of stress and coping frequently connected to families of children with disabilities (Wallander\&Varni, 1998). Moreover coping strategies assume a vital role in the well-being of mothers of children with autism (Smith et al. 2008).

Adaptive behavior refers to a person's social responsibility and independent performance of daily activities. Adaptive behavior is the performance of daily activities required for personal and social self - sufficiency across a variety of life situations including self-care (e.g. dressing and bathing), community mobility, home maintenance, establishing and maintaining relationships, and communicating needs and feelings (Sparrowet al, 2005).They are skills that a person learns in the process of adapting to his/her surroundings. Since adaptive behaviors are for the most part developmental (Hill, 2016).

Mothers have an autistic child are in need to get support. The day-to-day care of children with autism can be unpleasant. Ensuring that child gets the help he or she needs can likewise represent a challenge, contingent on whether quality support services are accessible or not. In the meantime, you are probably going to have progressing worries about your child's prognosis and long-term well-being (National institute of health, 2016).

Mothers with autism spectrum disorder can help children (ASD) to overcome their challenges. Also imperative to get the support, dealing, and taking care of them it's a necessity, being emotionally strong permits the parent to be ideal, accomplish the child' need and making life with an autistic child easier (Smith et al, 2016).

Significance of the study:

Extrapolation of incidence rate for autism in Egypt is 152,234 /total population (US Census Bureau, Population Estimates, 2015). There are only a select number of centers that can assist in detecting autism. The children diagnosed with autism always had a follow-up appointment to take care at outpatient clinics. Mothers present a widespread challenge however, providing care to a child with disabilities comes with unique demands. Most concerning in the domain of family support is that mothers of children with ASD experience notably higher rates of mothers' stress. The adaptive behaviors of children with autism were negatively correlated with parental behaviors which focused on continuing to seek and use social support, self-respect, and emotional strength. Mothers' views of the support their family received were positively correlated with mothers' behaviors that concentrated on family adjustment.

Aim of the study:

The aim of this study was to assess the effect of mothers' supportive care guidelines of coping patterns for the care of their children with autism through:

1. Assess mothers' knowledge and care of their children with autism

2. Develop supportive guideline intervention for mothers to coping with autistic disorders of their children.

3. Evaluate the effect of supportive guideline intervention for mothers to coping with autistic disorders of their children.

\section{Research hypothesis:}

1. Mothers having a non-satisfactory knowledge about autism.

2. The supportive care guidelines will improve the adaptive abilities of their children with autism and have a positive effect on coping patterns of mothers to care for their children with autism.

3. There is a relationship between characteristics of mothers and their coping patterns.

\section{Subjects and Method:}

\section{-Research design:}

The current study utilized a quasi-experimental design.

\section{Setting:}

The study was conducted in the out-patient clinic at Benha university Hospital, and Benha Educational Hospital (these settings only having clinics for children with autism).

\section{Subjects:}

A convenient sample consisted of all mothers and their children (40) diagnosed with autistic disorder admitted to the out-patient clinic at Benha university Hospital, and Benha Educational Hospital.

\section{Inclusion criteria:}

1. Mothers willing to co-operate for intervention.

2. Child Free from any medical complication or disorder.

3. Child Free from other Psychiatric disorder.

4. All children had a diagnosis of ASD. 


\section{Ethical consideration:}

All mothers and their children were informed about the aim of the study and its benefits in order to obtain their acceptance to participate. The researchers informed them that the participation in the study is voluntary; they have the right to withdraw from the study at any time, without giving any reason and that their responses would be held confidentially.

\section{Data Collection Tools:}

The following instruments were utilized to collect the required data:

\section{Tool I: A Structured Interviewing questionnaire.}

It was developed by the researchers after reviewing the relevant literature. This tool included two parts:

Part 1: Personal Characteristics of Children as age, gender, birth order

Part 2: Personal Characteristics of Mothers as: age, level of education, occupation, family number, and family income and the previous history of autism in the family

Part 3: mother's knowledge about autism.

Scoring system for knowledge; each correct response took two scores, the incomplete one took one score and the wrong answer or the not known response took no score with a total score of 20 represent $100 \%$. Total knowledge score above $(\geq 75 \%)$ considered good, score between $(60 \%$ - less than $75 \%)$ considered average, meanwhile mothers' total score(less than $60 \%$.) .

Part 4: children's practice was included, hand washing, cleaning the teeth, covering the face when coughing, care of self in the toilet.....

Scoring system for practice; each correct response took two scores, the incomplete one took one score and the wrong answer or the not known response took no score with a total score of 20 represent $100 \%$. Total Practice score above $(\geq 75 \%)$ considered competent and less than $75 \%$ was considered incompetent practice.

Tool II: Mothers' observational checklist regarding daily activity skills as motor, cognitive, social and communication.

Tool III: Coping health inventory for parent (CHIP) adopted from (McCubbin, et al, 1938) for assessment of parental coping patterns in the Care of a chronically ill child. It contains 45-item. Response format: Likert-type scale ( 1 = minimally helpful; 2 = moderately helpful; 3 = extremely helpful).

Tool IV: Adaptive behavior scale (ABS) adopted from (Lambert et al., 1993) adaptive behavior is the collection of conceptual, social, and practical skills that all people learn in order to function in their daily lives. ABS measures these three domains: Conceptual skills as a self concept, social skills as communication, and practical skills as activities of daily living. It includes 3 point in likert scale.

Scoring system for Adaptive; normal to average average took three scores, the below average took two score and extremely below average took 1 score with a total score of 20 represent $100 \%$. Total adaptive score above ( $\geq 60 \%$ ) considered Normal Adaptive and less than $60 \%$ was considered abnormal adaptive.

Tool V: family support scale adopted from (Dunst, Jenkins, \&Trivette, 1988). This scale assesses the helpfulness of informal and formal sources of support for raising a young child. There are 18 items included in this scale to identify their supports.

Tool VI: family supportive care guidelines which developed by the researcher for coping with children with autism. It is a booklet guideline for mothers to help them coping with their autistic children, include information about autism (definition, causes, signs\& symptoms, complications, treatment, and how to deal with an autistic child).

Validity and Reliability: Data collection tools were submitted to two experts of pediatric nursing to test the content validity. Modifications of the tools were done according to the expert's judgment on the clarity of sentences, appropriateness of content and sequence of items. The experts 'agreed on the content, according to their review few modifications were carried out in the content. The suggested changes were made. Regarding reliability, the reliability coefficientse ${ }^{\text {ee }}$ alpha between questions was 0.72 .

Pilot Study: A pilot study was conducted on $10 \%$ of mothers and their children to test the clarity and applicability of the tool and excluded from the studied sample.

\section{Field work:}

The aim of the current study was fulfilled the following phases; assessment phase, planning phase, implementation phase, and evaluation phase. The actual field work was carried out at pediatric out- patients' clinic from the beginning of May, 2016 until the end of October, 2016 in the previously mentioned settings covering six months. An official permission was obtained from the director of Benha University Hospital, and Benha Educational Hospital after clarifying the purpose of the study and the time for beginning the study. The researchers visited the previously mentioned settings two days/week the days of the appointment of the child at out -patient clinic from morning to the end time of the clinic until the predetermined sample size completed. The average time consumed to fill in the tools was 45 minutes. Assessment phase: This phase encompassed interviewing the participants to collect baseline data, at the beginning of the interview the researchers greeted the participation, introduced themselves to each participant included in the study, explained all information about the study purpose, duration, and activities and taken oral consent. The average time for the completion of

DOI: 10.9790/1959-0602021627 $\quad$ www.iosrjournals.org $\quad 18 \mid$ Page


each participant interview was around (30-45 minutes), average number collected was 2-3 participant / day. The total sample was divided into two groups then 10 subgroups include 5participant for each session. Planning phase: Based on the needs identified in the assessment phase and relevant review of literature, the researchers prepared Information and instructions was presented via: an question/answer session; a discussion session; demonstration and re-demonstration; and printed materials in the form of illustrated Arabic booklet provided by the researchers this phase take half an hour with each parent to evaluate their knowledge and skills during the 1 st and 3rd month after implementation program. Implementation phase: the researchers guided the mothers to fill the questionnaire sheet by themselves such as: knowledge about autism, daily living skills of the child and provide guidelines to help adaptive behavior of the child, and mothers' coping of the child. Each session takes approximately 10 to 15 minutes, during this time the participant were able to provide interventions, including all knowledge and skills regarding autism. An open channel communication was achieved between researcher and participant to ensure understanding, answer any question and to verify information given. Evaluation Phase: The mothers' knowledge and skills were evaluated in the 1st and 3rd months of guideline implementation.

Statistical analysis of data: The collected data were categorized, tabulated, and analyzed using the SPSS computer program Version 21. Numerical data were expressed as the mean and standard deviation. Qualitative data were expressed as frequency and percentage. The paired-sample t-test was used to compare the mothers' knowledge and skills mean scores at pre-test, the $1^{\text {st }}$ month and after 3 months of guideline implementation. Correlation among variables was done using Pearson correlation coefficient. The level of significance at $p<0.05$, $0.01,0.001$ were used as the cut of value for statistical significance.

\section{Results}

Table (1) showed that mother's mean age was $30.80 \pm 3.27$. Regarding mothers' education about $47 \%$ of them had a diploma, while $15 \%$ had the university. In relation to mother' occupation the majority of mothers were a housewife.

Table (2) revealed that $45 \%$ of children their age from 5 to less than 7 years with the mean age $\mathbf{5 . 0 2} \pm \mathbf{1 . 7 4}$, and the majority of them ( 67\%) are male. Related to child order $47 \%$ of them was the first child. Regarding relatives with the same diagnosis about two third $(72 \%)$ recorded that no relatives had an autistic child.

Table (3) illustrated that, the highest cognitive skills of an autistic children that the child does not achieve it was $82.5 \%, 70 \%$, and $62 \%$, respectively related to child usually makes eye contact when engaged in a conversation, child usually looks at you when you call by his/her name, your child make unusual finger movements in front of his/her eyes, and you point at something, your child is usually able to follow where you are looking at, or what you are pointing to.

Table (4) showed that the highest social skills that the child never achieved were $(100 \%),(70 \%)$, and $(52 \%)$ respectively related items child points at things to share what s/he might find interesting, child can usually understand if you, or someone in family is visibly upset, and child spontaneously looks you when faced with unfamiliar situation.

Table (5) revealed that the highest communication skills that the child never achieve were (92.5\%), $(82.5 \%)$, and $(72.5 \%)$ respectively related items way to describe YOUR emotion when you heard your child's first few words, your child have a habit of repeating words exactly the way they are told, and You and immediate family members can easily understand what your child may be trying to say (even though s/he may not have fully developed speech skills yet).

Table (6) showed that the highest sensory, motor, and behavioral skills of an autistic child were (90\%), (82.5\%), and $(77.5 \%)$ respectively related items child Tiptoe and/or Hand flap, child is usually good at using his/her hands in the right way when s/he needs to do something, and child has a habit of licking unusual objects or sniffing at things.

Table (7) showed that about $87 \%$ mothers were unsatisfactory about the level of knowledge about autism before the guideline and the mean score was $(2.65 \pm \mathbf{3 . 9 3})$, while immediately after guideline $90 \%$ of them were satisfactory and the mean score $(\mathbf{1 3 . 0 0} \pm \mathbf{2 . 1 2})$. There were highly significant relation $\mathrm{P}<0.001 * *$

Figure (1) Illustrated that the majority of family supports scale was (70\%) sometime available regarding social group item, followed by $(65.5 \%),(60 \%)$ not available regarding coworker, and school respectively. Also about $55 \%)$ was extremely helpful regarding intervention program.

Table (8) illustrated that there were highly significant difference in children practice of daily care before and After 3 month from guideline. And the mean score before the guideline was 3.372.13compared to $\mathbf{1 1 . 1 5} \pm \mathbf{6 . 8 6}$ after the guideline related to daily care, with highly significant statistically $(\mathrm{p}<0.001)$.

Table (9) showed that there was a highly significant difference in adaptive development scale of children before and after the guideline, the mean score was $\mathbf{3 0 . 6 5} \pm \mathbf{8 . 6 1}$ related to the adaptive independent function before implementation while after implementation was $\mathbf{5 4 . 4 2} \pm \mathbf{6 . 5 3}$. Related to the adaptive communication the mean score was before $29.00 \pm \mathbf{6 . 9 4}$ while after implantation was $\mathbf{5 2 . 6 0 0} \pm \mathbf{6 . 8 0}$. And in relation to the adaptive socialization the mean score before the program was $30.27 \pm \mathbf{5 . 1 3}$ compared to $\mathbf{5 7 . 4 2} \pm \mathbf{5 . 7 9}$, after the guideline with highly significant statistically $(\mathrm{p}<0.001)$. 
Table (10) illustrated that there was a highly significant difference in coping behavior scale of parent between before and after the guideline. And the mean score before the program was 36.77 \pm 1.77 compared to 16.67 \pm 3.90 after the program related to the maintaining integration and cooperation with the situation. In relation to the maintaining social support, self esteem, and psychological stability the mean score was $\mathbf{4 2 . 9 5 \pm 2 . 2 4}$ as compared to after implantation was $\mathbf{1 3 . 7 9} \pm \mathbf{3 . 4 5}$ respectively. Meanwhile the understand the medical situation through communication with other mothers and consultation with medical staff the mean score was 17.52 \pm $\mathbf{2 . 5 7}$ before implantation while after implantation was $\mathbf{5 . 8 0} \pm \mathbf{4 . 0 0}$. with highly significant statistically $(\mathrm{p}<0.001)$. Table (11) revealed that there were highly significant statistically correlation between total parent's knowledge and their age and level of education $(\mathrm{p}<0.001)$.it illustrated that, there was the positive relation with increase age and level of education the knowledge increase.

Table (12) illustrated that there was a highly significant correlation between total children's adaptive scale and their age before and after the program $\mathrm{P}<0.001$. There was the positive relation.

Table (13) illustrated there was no significant statically correlation between mothers' total coping scale and their age before the program implementation $\mathrm{P}>0.005$, and there was a highly significant correlation after program implementation $\mathrm{P}<0.001$.

Table (1): Distribution of the Mothers according to Personnel Characteristics $(n=40)$.

\begin{tabular}{|l|c|c|}
\hline \multicolumn{1}{|c|}{ Characteristics } & NO & \% \\
\hline Age/year: & 19 & 47.5 \\
-25 less than 30 & 16 & 40.0 \\
-30- less than35 & 5 & 12.5 \\
-Above 35 years & \multicolumn{2}{|c|}{$\mathbf{3 0 . 8 0 \pm 3 . 2 7}$} \\
\hline Mean SD & 19 & 47.5 \\
\hline The level of mother's education: & 15 & 37.5 \\
-Diploma & 6 & 15.0 \\
-Secondary education & 14 & 35.0 \\
- university & 26 & 65.0 \\
\hline Mother's occupation: & & \\
\hline -Work & & \\
\hline
\end{tabular}

Table (2): Distribution of the Children according to Personnel Characteristics

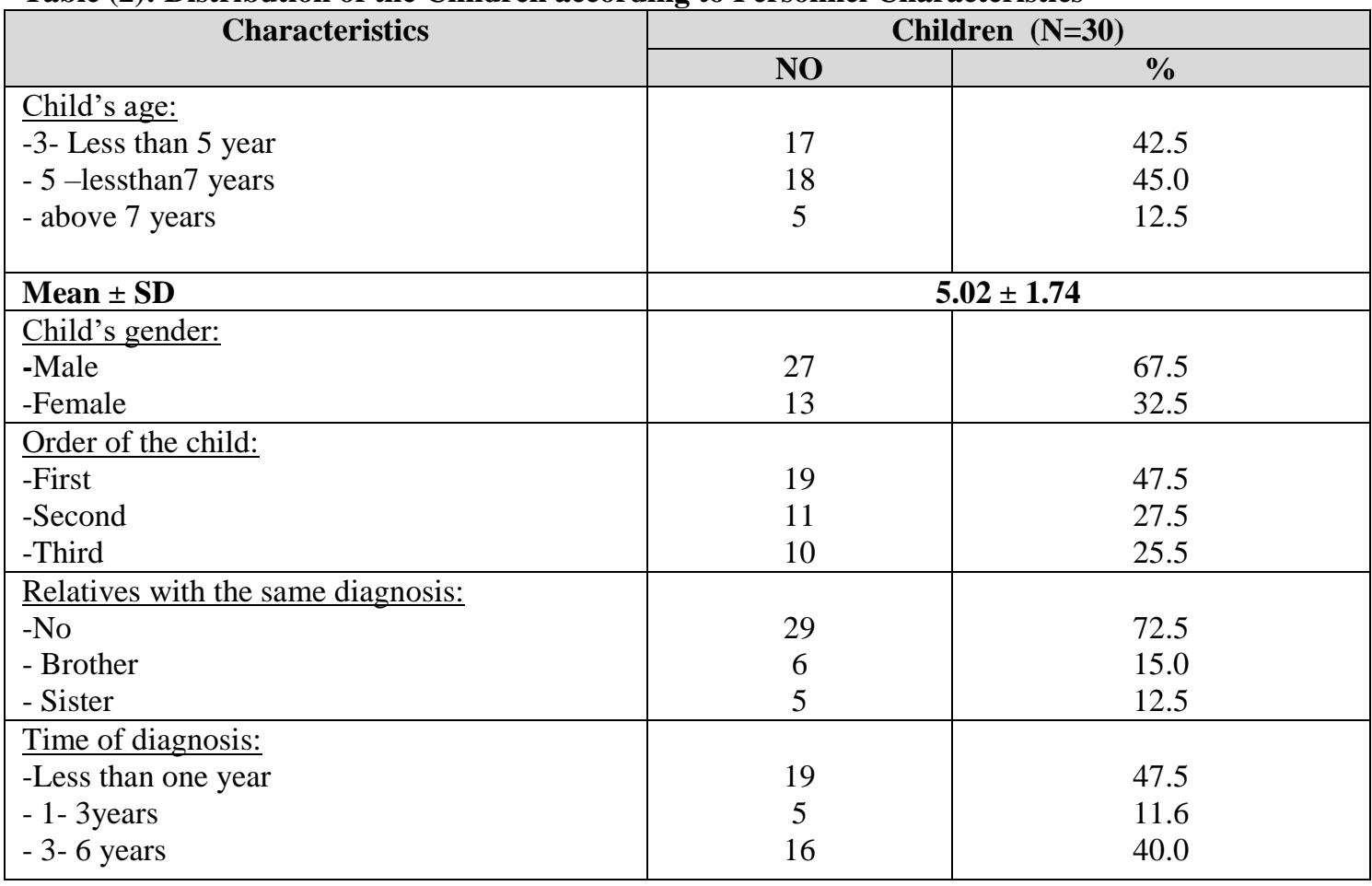




\begin{tabular}{|l|c|c|}
\hline - child suffer from any others problems: & 40 & 100.0 \\
\hline - No & 0 & 0.0 \\
& & \\
\hline
\end{tabular}

Table (3): Distribution of Mothers' Observation Checklist regarding Cognitive Skills of Autistic Children.

\begin{tabular}{|l|c|c|c|c|c|c|}
\hline \multirow{2}{*}{ Items } & \multicolumn{2}{|c|}{ Always } & \multicolumn{2}{c|}{ Sometimes } & \multicolumn{2}{c|}{ Never } \\
\cline { 2 - 6 } & $\mathrm{N}$ & $\%$ & $\mathrm{~N}$ & $\%$ & $\mathrm{~N}$ & \\
\hline $\begin{array}{l}\text { Your child usually looks at you when } \\
\text { you call by his/her name }\end{array}$ & 0 & 0.0 & 12 & 30.0 & 28 & 70.0 \\
\hline $\begin{array}{l}\text { Your child usually makes eye contact } \\
\text { when engaged in a conversation }\end{array}$ & 3 & 7.5 & 4 & 10.0 & 33 & 82.5 \\
\hline $\begin{array}{l}\text { How long, do you think, your child } \\
\text { usually spends looking at a spinning } \\
\text { object }\end{array}$ & 21 & 52.5 & 12 & 30.0 & 7 & 17.5 \\
\hline $\begin{array}{l}\text { If you point at something, your child is } \\
\text { usually able to follow where you are } \\
\text { looking at, or what you are pointing to }\end{array}$ & 4 & 10.0 & 11 & 27.5 & 25 & 62.5 \\
\hline $\begin{array}{l}\text { Does your child make unusual finger } \\
\text { movements in front of his/her eyes? }\end{array}$ & 0 & 0.0 & 12 & 30.0 & 28 & 70.0 \\
\hline $\begin{array}{l}\text { How would rate of your } \\
\text { child's sensitivity to noise }\end{array}$ & 3 & 7.5 & 13 & 32.5 & 24 & 60.0 \\
\hline
\end{tabular}

Table (4): Distribution of Mothers' Observation Checklist regarding Social Skills of Autistic Children

\begin{tabular}{|l|c|c|c|c|c|c|}
\hline \multirow{2}{*}{ Items } & \multicolumn{2}{|c|}{ Always } & \multicolumn{2}{c|}{ Sometimes } & \multicolumn{2}{c|}{ Never } \\
\cline { 2 - 6 } & $\mathrm{N}$ & $\%$ & $\mathrm{~N}$ & $\%$ & $\mathrm{~N}$ & $\%$ \\
\hline $\begin{array}{l}\text { Your child points at things to share what s/he } \\
\text { might find interesting }\end{array}$ & 0 & 0.0 & 0 & 0.0 & 40 & 100.0 \\
\hline $\begin{array}{l}\text { Your child can usually understand if you, or } \\
\text { someone in the immediate family is visibly } \\
\text { upset and s/he attempts to comfort you (or the } \\
\text { other member) }\end{array}$ & 2 & 5.0 & 10 & 25.0 & 28 & 70.0 \\
\hline $\begin{array}{l}\text { Your child is usually good at interpreting } \\
\text { simple gestures and would return the same }\end{array}$ & 6 & 15.0 & 15 & 37.5 & 19 & 47.5 \\
\hline $\begin{array}{l}\text { Your child spontaneously looks at you when } \\
\text { faced with an unfamiliar situation }\end{array}$ & 6 & 15.0 & 13 & 35.0 & 21 & 52.0 \\
\hline
\end{tabular}

Table (5): Distribution of Mother's Observation Checklist regarding Communication Skills of Autistic Children

\begin{tabular}{|c|c|c|c|c|c|c|}
\hline \multirow[t]{2}{*}{ Items } & \multicolumn{2}{|c|}{ Always } & \multicolumn{2}{|c|}{ Sometimes } & \multicolumn{2}{|c|}{ Never } \\
\hline & $\mathrm{N}$ & $\%$ & $\mathrm{~N}$ & $\%$ & $\mathrm{~N}$ & $\%$ \\
\hline $\begin{array}{l}\text { You and immediate family members can easily understand } \\
\text { what your child may be trying to say (even though s/he } \\
\text { may not have fully developed speech skills yet) }\end{array}$ & 0 & 0.0 & 11 & 27.5 & 29 & 72.5 \\
\hline $\begin{array}{l}\text { Your child is adept at using sign language to point out } \\
\text { what } s / \text { he wants }\end{array}$ & 5 & 12.5 & 11 & 27.5 & 24 & 60.0 \\
\hline $\begin{array}{l}\text { The best way to describe YOUR emotion when you heard } \\
\text { your child's first few words would be? }\end{array}$ & 0 & 0.0 & 3 & 7.5 & 37 & 92.5 \\
\hline $\begin{array}{l}\text { Does your child have a habit of repeating words exactly } \\
\text { the way they are told? }\end{array}$ & 0 & 0.0 & 7 & 17.5 & 33 & 82.5 \\
\hline
\end{tabular}

Table (6): Distribution of Mothers' Observation Checklist regarding Sensory, Motor \& Behavioral Skills of Autistic Children 


\begin{tabular}{|c|c|c|c|c|c|c|}
\hline \multirow[t]{2}{*}{ Items } & \multicolumn{2}{|c|}{ Always } & \multicolumn{2}{|c|}{ Sometimes } & \multicolumn{2}{|c|}{ Never } \\
\hline & $\mathrm{N}$ & $\%$ & $\mathrm{~N}$ & $\%$ & $\mathrm{~N}$ & $\%$ \\
\hline $\begin{array}{l}\text { Your child always like to line up his/her toys, or arrange } \\
\text { them in 'a' specific order, every time }\end{array}$ & 5 & 12.5 & 9 & 22.5 & 26 & 65.0 \\
\hline Your child is usually good at pretending while playing & 3 & 7.5 & 9 & 22.5 & 28 & 70.0 \\
\hline $\begin{array}{l}\text { Your child has a habit of licking unusual objects or } \\
\text { sniffing at things }\end{array}$ & 2 & 5.0 & 7 & 17.5 & 31 & 77.5 \\
\hline Does your child Tip toe and/or Hand flap? & 0 & 0.0 & 4 & 10.0 & 36 & 90.0 \\
\hline $\begin{array}{l}\text { How does your child react when there is a sudden change } \\
\text { in plan or things are out of usual space }\end{array}$ & 0 & 0.0 & 16 & 40.0 & 24 & 60.0 \\
\hline $\begin{array}{l}\text { Your child has an odd habit of doing the same thing over } \\
\text { and over again }\end{array}$ & 3 & 7.5 & 13 & 32.5 & 24 & 60.0 \\
\hline $\begin{array}{l}\text { Your child spends time staring at something (or nothing) } \\
\text { for too long without any apparent reason }\end{array}$ & 15 & 37.5 & 15 & 37.5 & 10 & 25.0 \\
\hline
\end{tabular}

Table (7): Distribution and Mean Differences of total Mother's Level of Knowledge regarding Autism Before, Immediately after and After 3 month

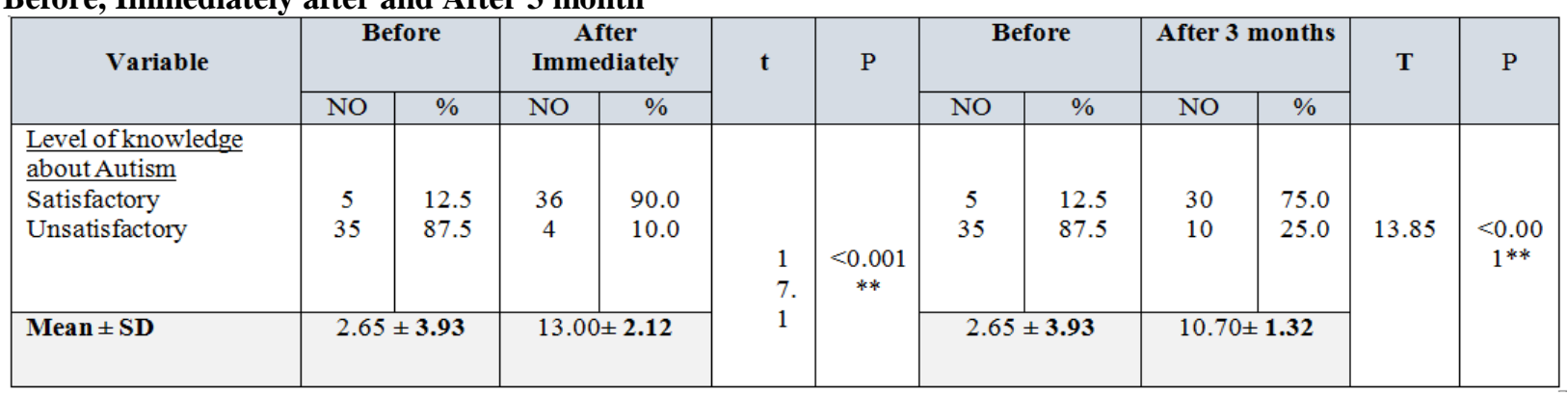

Figure (1): Distribution of Family Support scale regarding their Autistic Children

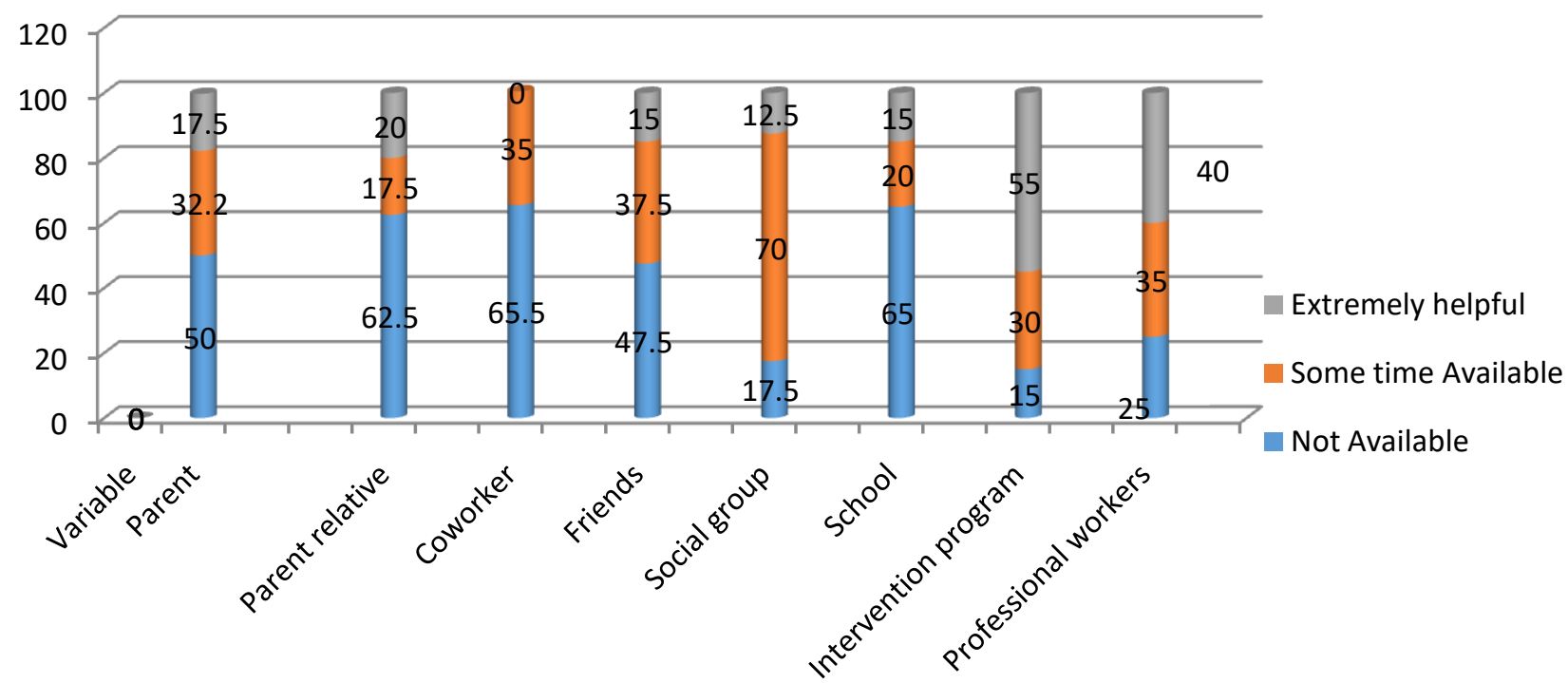


Mothers' supportive care guidelines of coping Pattern for the care of their children with autism

Table (8) distribution of Children according to their practice about of daily care Before and After 3 month from Guideline.

\begin{tabular}{|c|c|c|c|c|c|c|c|c|c|c|c|c|c|c|}
\hline \multirow[t]{3}{*}{ Items } & \multicolumn{6}{|c|}{ Before implementation } & \multicolumn{6}{|c|}{ After Implementation } & \multirow{3}{*}{$\mathrm{X}^{2}$} & \multirow{3}{*}{$\mathrm{p}$} \\
\hline & \multicolumn{2}{|c|}{ Not done } & \multicolumn{2}{|c|}{$\begin{array}{l}\text { Done but } \\
\text { incomplete }\end{array}$} & \multicolumn{2}{|c|}{$\begin{array}{l}\text { Done } \\
\text { complete }\end{array}$} & \multicolumn{2}{|c|}{ Not done } & \multicolumn{2}{|c|}{$\begin{array}{l}\begin{array}{l}\text { Done but } \\
\text { incomplete }\end{array}\end{array}$} & \multicolumn{2}{|c|}{ Done complete } & & \\
\hline & $\mathrm{N}$ & $\%$ & $\mathrm{~N}$ & $\%$ & $\mathrm{~N}$ & $\%$ & $\mathrm{~N}$ & $\%$ & $\mathrm{~N}$ & $\%$ & $\mathrm{~N}$ & $\%$ & & \\
\hline Wash hands & 25 & 62.5 & 10 & 30 & 5 & 12.5 & 10 & 25 & 10 & 25 & 20 & 50 & 10.2 & $\begin{array}{c}<0.00 \\
1\end{array}$ \\
\hline $\begin{array}{l}\text { Covering the mouth } \\
\text { when cough }\end{array}$ & 33 & 82.5 & 7 & 17.5 & 0 & 0.0 & 8 & 20 & 14 & 35 & 18 & 45 & 3.11 & $\begin{array}{l}<0.00 \\
5\end{array}$ \\
\hline Cleaning the teeth & 33 & 82.5 & 7 & 17.5 & 0 & 0.0 & 8 & 20 & 21 & 25.5 & 11 & 27.5 & 10.34 & $\begin{array}{c}<0.00 \\
1\end{array}$ \\
\hline Toilet training & 20 & 50 & 7 & 17.5 & 13 & 32.5 & 11 & 27.5 & 6 & 15 & 23 & 57.5 & 6.27 & $\begin{array}{c}<0.00 \\
5\end{array}$ \\
\hline Care of self in bath room & 29 & 72.5 & 11 & 27.5 & 0 & 0.0 & 7 & 17.5 & 23 & 57.5 & 10 & 25 & 11.2 & $\begin{array}{c}<0.00 \\
1\end{array}$ \\
\hline Regular bath or shower & 25 & 62.5 & 15 & 37.5 & 0 & 0.0 & 10 & 25 & 16 & 40 & 14 & 35 & 8.57 & $\begin{array}{c}<0.00 \\
5\end{array}$ \\
\hline Dressing skills & 23 & 57.5 & 17 & 42.5 & 0 & 0.0 & 8 & 20 & 14 & 35 & 18 & 45 & 21.5 & $\begin{array}{c}<0.00 \\
1\end{array}$ \\
\hline $\begin{array}{l}\text { Appropriate eating } \\
\text { behavior }\end{array}$ & 32 & 80 & 8 & 20 & 0 & 0.0 & 12 & 30 & 21 & 52.5 & 7 & 17.5 & 9.04 & $\begin{array}{c}<0.00 \\
5\end{array}$ \\
\hline Seating on the table & 33 & 82.5 & 7 & 17.5 & 0 & 0.0 & 12 & 30 & 20 & 50 & 8 & 20 & 8.48 & $\begin{array}{l}<0.00 \\
5\end{array}$ \\
\hline Good sleep habits & 28 & 70 & 12 & 30 & 0 & 0.0 & 11 & 27.5 & 15 & 37.5 & 14 & 35 & 6.53 & $\begin{array}{l}<0.00 \\
5\end{array}$ \\
\hline Mean \pm SD & & & 3.37 & & & & & & & $5 \pm 6.8$ & & & $\mathrm{t}=-9.37$ & $\begin{array}{l}<0.00 \\
1\end{array}$ \\
\hline
\end{tabular}

Table (9): Total Adaptive Development scale of children before and after implementation the Guideline

\begin{tabular}{|c|c|c|c|c|c|c|c|c|c|c|c|c|c|c|}
\hline \multirow[t]{3}{*}{ Items } & \multicolumn{6}{|c|}{ Before implementation } & \multicolumn{6}{|c|}{ After Implementation } & \multirow{3}{*}{$\mathrm{X}^{2}$} & \multirow{3}{*}{$\mathbf{p}$} \\
\hline & \multicolumn{2}{|c|}{$\begin{array}{l}\text { Extremely } \\
\text { Below Average }\end{array}$} & \multicolumn{2}{|c|}{ Below Average } & \multicolumn{2}{|c|}{$\begin{array}{l}\text { Near or At to } \\
\text { average }\end{array}$} & \multicolumn{2}{|c|}{$\begin{array}{l}\text { Extremely } \\
\text { Below } \\
\text { Average }\end{array}$} & \multicolumn{2}{|c|}{ Below Average } & \multicolumn{2}{|c|}{$\begin{array}{l}\text { Near or At to } \\
\text { average }\end{array}$} & & \\
\hline & $\mathrm{N}$ & $\%$ & $\mathrm{~N}$ & $\%$ & $\mathrm{~N}$ & $\%$ & $\mathrm{~N}$ & $\%$ & $\mathrm{~N}$ & $\%$ & $\mathrm{~N}$ & $\%$ & & \\
\hline Adaptive Independent function & 31 & 77.5 & 9 & 22.5 & 0 & 0.0 & 0 & 0.0 & 12 & 30.0 & 28 & 70.0 & 4.97 & $<0.005$ \\
\hline Mean \pm SD & \multicolumn{6}{|c|}{$30.65 \pm 8.61$} & \multicolumn{6}{|c|}{$54.42 \pm 6.53$} & $\mathrm{t}=-18.34$ & $<0.001$ \\
\hline Adaptive Communication & 31 & 77.5 & 7 & 17.5 & 2 & 5.0 & 0 & 0.0 & 4 & 27.5 & 29 & 72.5 & 4.4 & $<0.005$ \\
\hline Mean \pm SD & \multicolumn{6}{|c|}{$29.00 \pm 6.94$} & \multicolumn{6}{|c|}{$52.600 \pm 6.80$} & $\mathrm{t}=-19.31$ & $<0.001$ \\
\hline Adaptive Socialization & 32 & 80.0 & 8 & 20.0 & 0 & 0.0 & 0 & 0.0 & 6 & 15.0 & 34 & 85.0 & 1.77 & $<0.005$ \\
\hline Mean \pm SD & \multicolumn{6}{|c|}{$30.27 \pm 5.13$} & \multicolumn{6}{|c|}{$57.42 \pm 5.79$} & $\mathrm{t}=-23.11$ & $<0.001$ \\
\hline
\end{tabular}

Table (10) Total Frequencies and Mean Distribution of Coping Behavior Scale of Mothers Before and After Implementation the guideline 


\begin{tabular}{|c|c|c|c|c|c|c|c|c|c|c|c|c|c|c|}
\hline \multirow[t]{3}{*}{ Items } & \multicolumn{6}{|c|}{ Before implementation } & \multicolumn{6}{|c|}{ After Implementation } & \multirow{3}{*}{$\mathrm{X}^{2}$} & \multirow{3}{*}{$\mathrm{p}$} \\
\hline & \multicolumn{2}{|c|}{$\begin{array}{l}\text { Extremely } \\
\text { Helpful }\end{array}$} & \multicolumn{2}{|c|}{$\begin{array}{l}\text { Moderately } \\
\text { helpful }\end{array}$} & \multicolumn{2}{|c|}{$\begin{array}{l}\text { Minimally } \\
\text { helpful }\end{array}$} & \multicolumn{2}{|c|}{$\begin{array}{l}\text { Extremely } \\
\text { Helpful }\end{array}$} & \multicolumn{2}{|c|}{$\begin{array}{l}\text { Moderately } \\
\text { helpful }\end{array}$} & \multicolumn{2}{|c|}{ Minimally helpful } & & \\
\hline & $\mathrm{N}$ & $\%$ & $\mathrm{~N}$ & $\%$ & $\mathrm{~N}$ & $\%$ & $\mathrm{~N}$ & $\%$ & $\mathrm{~N}$ & $\%$ & $\mathrm{~N}$ & $\%$ & & \\
\hline $\begin{array}{l}\text { Maintaining family integration, } \\
\text { cooperation, and an optimistic } \\
\text { definition of the situation }\end{array}$ & 11 & 27.5 & 29 & 72.5 & 0 & 0.0 & 0 & 0.0 & 0 & 0.0 & 40 & 100.0 & 105.3 & $<0.005$ \\
\hline Mean \pm SD & \multicolumn{6}{|c|}{$36.77 \pm 1.77$} & \multicolumn{6}{|c|}{$16.67 \pm 3.90$} & $t=-27.56$ & $<0.001$ \\
\hline $\begin{array}{l}\text { Maintaining social support, self- } \\
\text { esteem and psychological stability }\end{array}$ & 37 & 92.5 & 3 & 7.5 & 0 & 0.0 & 0 & 0.0 & 0 & 0.0 & 40 & 100.0 & 109.9 & $<0.001$ \\
\hline Mean \pm SD & \multicolumn{6}{|c|}{$42.95 \pm 2.24$} & \multicolumn{6}{|c|}{$13.79 \pm 3.45$} & $t=-34.15$ & $<0.001$ \\
\hline Mean \pm SD & \multicolumn{6}{|c|}{$17.52 \pm 2.57$} & \multicolumn{6}{|c|}{$5.80 \pm 4.00$} & $t=-18.85$ & $<0.001$ \\
\hline
\end{tabular}

Table (11) Correlation between Total Mothers' Knowledge and their Age and Level of Education

\begin{tabular}{|l|c|c|}
\hline Total Knowledge & Age & Level of Education \\
\hline Total Knowledge before & .430 & .871 \\
R & $<0.001$ & $<0.001$ \\
P & & .430 \\
\hline Total Knowledge after & .414 & $<0.001$ \\
R & $<0.001$ & \\
P & & \\
\hline
\end{tabular}

Table (12) Correlation between Total Children Adaptive Scale and their Age

\begin{tabular}{|l|c|c|}
\hline \multirow{2}{*}{ Items } & \multicolumn{2}{|c|}{ Age } \\
\cline { 2 - 3 } & R & P \\
\hline Total Adaptive before & .691 & $<0.001$ \\
\hline Total Adaptive after & -.627 & $<0.001$ \\
\hline
\end{tabular}

Table (13) Correlation between Total Mothers' Coping Scale and their Age

\begin{tabular}{|l|c|c|}
\hline \multirow{2}{*}{ Items } & \multicolumn{2}{|c|}{ Age } \\
\cline { 2 - 3 } Total coping before & R & P \\
\hline Total coping after & .175 & $>0.005$ \\
& & \\
\hline
\end{tabular}




\section{Discussion}

Autism spectrum disorder (ASD) covers a set of developmental disabilities that can cause significant social, communication, and behavioral challenges. People with ASD process information in their brain differently than other people (National Institute on Deafness and Other Communication Disorders, 2016). The aim of this study was to Assess the effect mothers' supportive care guidelines of coping patterns for the care of their children with autism. The present study revealed that the majority more than half $(67 \%)$ of children with autism are a male table (2). This finding supported with the report of (Centers for Disease Control and Prevention, 2016). Reported that is about 4.5 times more common among boys. Also (Autism Speak, 2016), reported that Boys are nearly five times more likely than girls to have autism. In relation to mothers' knowledge and practice the present study showed that there were unsatisfactory about the level of knowledge about autism before the guideline that emphasized the importance of providing mothers with effective knowledge and practice about autism for best outcomes of the intervention. Regarding the sources of the family support figure (1) indicated that more than half $(55 \%)$ of the intervention program as the source of the family support extremely helpful. $70 \%$ of social group sometimes available as a source of the family support. while two third $62 \%$ \& $65 \%$ of parent relative and coworker didn't available as a source of the family support of an autistic child. Sources of family support are the way that helps mothers coping effectively with their autistic children and handle stress.

Autistic child unable to successfully communicate and interact with others. Children with ASD may have difficulty developing language skills and understanding what others say to them. They also may have difficulties communicating nonverbally, such as through hand gestures, eye contact, and facial expressions (National Institute on Deafness and Other Communication Disorders, 2016).

Regarding cognitive skills table (3) indicated that the child has speech and language problems, In relation to social skills table (4) revealed that difficulty regulating their emotions, not interact and they avoid eye contact, this finding supported by (Williams, et al, 2007). However, communication skills table(5), showed that an autistic child has difficulty developing language skills and understanding what others say to them and they also may have difficulties communicating nonverbally, such as through hand gestures, eye contact, and facial expressions. This finding agrees with (Matson, et al, 2007).Regarding motor skills table (6) indicated that the child has uncontrolled muscle of hands, legs, and surrounding the eyes. These results supported by (Wertz, 2012). This skills problem required more attention and should be determined effectively and implementation training for effective outcomes for child and mothers.

Concerning, the adaptive developmental scale of children table (8) showed that there was a highly significant difference in adaptive development scale of the child before and after the guideline related to the adaptive communication and adaptive socialization. To assess adaptive behavior of autistic child help to identify of the development of daily living skills of the child the way to improve it and for effective outcomes (Andrew, 2008). Regarding to coping behavior scale of mothers table(9) illustrated that was a highly significant difference in coping behavior scale of parent between before and after the guideline that were achieved through the understand the medical situation through communication with other mothers have autistic child and consultation with medical staff. These findings were supported by (Boyd, 2002). That emphasized that contact with supportive family members and mothers of other children with autism were one of the important coping strategies and decreased parental stress.

In relation to knowledge and their level of education table (10) revealed there were highly significant correlations between mothers' knowledge and their level of education and age. These results were agreed with (Parvin, et al, 2015), (Muhammad, et al, 2013) \& (Imran, et al, 2011).

\section{Conclusion}

The supportive care guidelines improved the adaptive abilities of their children with autism and had a positive effect on coping patterns of mothers to care for their children with autism.

The present study concluded that there was a highly significant difference in adaptive development scale of the child, and also there was a highly significant difference in coping behavior scale of parent before and after the guideline. This indicated that the mother supportive care guidelines improved the adaptive abilities of their children with autism.

\section{Recommendations}

- Encourage early diagnosis and intensive intervention is vital to the successful development of the children.

- Apply the family supportive care guidelines and program to improve adaptive abilities of children with autism.

- The faculties of nursing should include a physical care and treatment in their curriculums to improve skills of the autistic children.

- Educate the autistic children the normal life style through play.

- Encourage the family to strength social communicational skills of the autistic children through the inclusion of them social activities.

- Use effective coping strategies to deal with the children with autism.

- Further studies to support mothers with autistic child and decrease their stress. 


\section{References}

[1]. American Psychiatric Association. (2013): Neurodevelopment disorders. In Diagnostic and Statistical Manual of Mental Disorders, 5th ed., pp. 31-86. Washington, DC: American Psychiatric Association.

[2]. Andrew Chambers (2008): Impulsivity, dual diagnosis, and the structure of motivated behavior in addiction. Behavioral and Brain Sciences, 31, pp 443-444 doi:10.1017/S0140525X08004792

[3]. Autism Speaks (2016): Autism Speaks Inc..

[4]. Boyd, B. A. (2002): Examining the relationship between stress and lack of social support in mothers of children with autism. Focus on Autism and Other Developmental Disabilities, 17, 208 -215.

[5]. Brad Hill. (2016): Vineland Adaptive Behavior Scales. last updated: July 7, 2016

[6]. Canty-Mitchell, J. \&Zimet, G.D.(2000): Psychometric properties of the Multidimensional Scale of Perceived Social Support in urban adolescents. American Journal of Community Psychology, 28, 391400.

[7]. Carver, Charles S.; Connor-Smith, Jennifer. (2010):"Personality and Coping". Annual Review of Psycho.61:679-704. doi:10.1146/annurev.psych.093008.100352.PMID 19572784

[8]. Centers for Disease Control and Prevention (2016): History of CDC Autism Prevalence Study Results. AUTISM NEW JERSEY

[9]. Centers for Disease Control and Prevention. (2014): Autism Prevalence Study Results. March 27, 2014

[10]. Connie Anderson.( 2010): Reliving parental stress and depression: How helping mothers helps children. IAN Online Community Facilitator. Kennedy Krieger Institute.

Email: ian@kennedykrieger.org

[11]. Dunst, C. J., Jenkins, V., \&Trivette, C. M. (1988): Family Support Scale. In C. J. Dunst, C. M. Trivette, and A. G. Deal (Eds.), Enabling and empowering families: Principles and guidelines for practice (pp. 153-174). Cambridge, MA: Brookline Books.

[12]. Imran N, Chaudry MR, Azeem MW, Bhatti MR. ( 2011): A survey of Autism knowledge and

[13]. Lambert, N., Nihira, K., \& Leland, H. (1993): AAMR Adaptive Behavior Scale-School (2nd ed.). Austin, TX: American Association on Mental Retardation.

[14]. Matson, J. L., Matson, M. L., \& Rivet, T. T. (2007): Social-skills treatments for children with autism spectrum disorders: An overview. Behavior Modification, 31(5), 682-707.

[15]. McCubbin, H.I., McCubbin, M.A., Patterson, J.M., Cauble, A.E., Wilson, L.R. \& Warwick, W. (1983):CHIP-Coping Health Inventory for Mothers: An Assessment of Parental Coping Patterns in the Care of the Chronically Ill Child. Journal of Marriage and the Family, 359-370.

[16]. Melinda Smith, M.A., Jeanne Segal, Ph.D., and Ted Hutman, Ph.D. (2016): Helping Your Child with Autism Thrive Last updated: October 2016.

[17]. Mental health wellness week. 2009: Strategies for good Mental health wellness.Adapted from the Canadian Mental Health Association of Richmond, BC

[18]. Muhammad M, Ayesha N, Farah A. (2013): Awareness of Autism in Primary School Teachers, Autism Res Treat 2013; 961595.

[19]. National Institute of Neurological Disorders and Stroke. (2016): Office of Communications and Public Liaison. National Institute of Neurological Disorders and Stroke. National Institutes of Health. Bethesda, MD 20892. Last Modified February 1, 2016

[20]. National Institute on Deafness and Other Communication Disorders. (2016): Autism Spectrum Disorder: Communication Problems in Children. March 21, 2016. 31 Center Drive, MSC 2320, Bethesda, MD USA 20892-2320

[21]. National Institutes of Health.(2016):"Gene linked to autism in families with more than one affected child." Reviewed by SmithaBhandari. 2016: Parenting a Child With Autism. ebMD Medical Reference Reviewed by on May 31, 2016

[22]. Paltrow, C. (2015): 4 Ways a Child with Autism Affects Family Life. Psych Central. Retrieved on October 22, 2016, from http://psychcentral.com/blog/archives/2015/02/25/4-ways-a-child-with-autismaffects-family-life/

[23]. Parvin MN , Haque MM , Bhuiyan MR , Haqe M , Saha PK , Islam ASMM. (2015): Knowledge onCare of Autistic Child among the Mother's AttendingProtibondhi Foundation, Dhaka. Bangladesh Journal of Medical Science Vol. 14 No. 02 April'15. DOI: http://dx.doi.org/10.3329/bjms.v14i2.21563 Bangladesh Journal of Medical Science Vol.14(2) 2015 p.179-183

[24]. Smith, L. E., Seltzer, M. M., Tager-Flusberg, H., Greenberg, J.S., Carter, A. S. (2008): A comparative analysis of well-being and coping among mothers of toddlers and Parenting Stress in Mothers and Fathers of Children with Autism Spectrum Disorders 105 mothers of adolescents with ASD. Journal of Autism and Developmental Disorders, 38, 5, 876-889.

[25]. Sparrow SS, Cicchetti D, Balla D. Vineland. (2005): Adapted behavior scales, second edition (Vineland-II) Circle Pines, MN: American Guidance Service. 
[26]. US Census Bureau.(2015): Population Estimates, International Data Base, 2004 Last Update: 13 August, 2015

[27]. Wallander, J.L.,Varni, J.W. ( 1998): Effects of pediatric chronic physical disorders on children and family adjustment.Journal of Child Psychology and Psychiatry 1998; 39: 29-46.

[28]. Wertz.S. R. (2012): Movement Difficulties in Children with Autistic Disorder

[29]. Williams White, S., Koenig, K., \&Scahill, L. (2007): Social skills development in children with autism spectrum disorders: A review of the intervention research. Journal of Autism and Developmental Disorders, 37(10), 1858-1868. 